\title{
Uncoupling proteins in the failing human heart: friend or foe?
}

Citation for published version (APA):

Hesselink, M. K., \& Schrauwen, P. (2005). Uncoupling proteins in the failing human heart: friend or foe? Lancet, 365(9457), 385-386. https://doi.org/10.1016/S0140-6736(05)17823-4

Document status and date:

Published: 01/01/2005

DOI:

10.1016/S0140-6736(05)17823-4

Document Version:

Publisher's PDF, also known as Version of record

Document license:

Taverne

Please check the document version of this publication:

- A submitted manuscript is the version of the article upon submission and before peer-review. There can be important differences between the submitted version and the official published version of record.

People interested in the research are advised to contact the author for the final version of the publication, or visit the DOI to the publisher's website.

- The final author version and the galley proof are versions of the publication after peer review.

- The final published version features the final layout of the paper including the volume, issue and page numbers.

Link to publication

\footnotetext{
General rights rights.

- You may freely distribute the URL identifying the publication in the public portal. please follow below link for the End User Agreement:

www.umlib.nl/taverne-license

Take down policy

If you believe that this document breaches copyright please contact us at:

repository@maastrichtuniversity.nl

providing details and we will investigate your claim.
}

Copyright and moral rights for the publications made accessible in the public portal are retained by the authors and/or other copyright owners and it is a condition of accessing publications that users recognise and abide by the legal requirements associated with these

- Users may download and print one copy of any publication from the public portal for the purpose of private study or research.

- You may not further distribute the material or use it for any profit-making activity or commercial gain

If the publication is distributed under the terms of Article $25 \mathrm{fa}$ of the Dutch Copyright Act, indicated by the "Taverne" license above, 


\section{Author's reply}

Jason Gardosi makes two points. The first is that doctors should be cautious about applying our results indiscriminately, because they might not be generalisable to the whole population of babies for whom early delivery is considered. Doctors who are faced with babies who they believe are less sick than those recruited to GRIT should obviously delay delivery. Equally, those treating babies who they believe are more sick, might decide to ignore our results and deliver. Their decision should be based on the results of observational studies, which can provide guidance on timing delivery to prevent fetal death. These studies are, however, a poor guide to timing delivery with the aim of reducing brain damage. We believe, in this instance, the GRIT results are better.

Gardosi's second point is more controversial. He suggests that doctors might have preferentially recruited patients for whom they believed a delay was preferable, so the trial gave them the result they wanted. However, he provides no justification for his belief that doctors would prefer one outcome over the other. The argument that specialists in fetal medicine, much of whose clinical practice is devoted to delivering babies early in the hope that they can prevent death and brain damage, would have hoped for the opposite result is just as strong. Irrespective of personal preferences, however, such behaviour would have been unethical. Furthermore, even if recruitment had been biased, the internal validity of the trial would not have been affected-for babies of the same gestational ages and with the same Doppler waveforms as those studied, the GRIT results are valid.

I declare that I have no conflict of interest.

\section{Jim Thornton}

Jim.thornton@nottingham.ac.uk

Department of Obstetrics and Gynaecology, City Hospital, Nottingham NG5 1PB, UK

\section{Uncoupling proteins in the failing human heart: friend or foe?}

Concentrations of circulating free fatty acids are increased in patients with heart disease and are inversely correlated with myocardial phosphocreatine-to-ATP ratio, an indicator of cardiac energy deficit. Andrew Murray and colleagues (Nov 13, p 1786) ${ }^{1}$ report a positive relation between the concentration of circulating free fatty acids and the content of cardiac mitochondrial uncoupling proteins, and suggest this relation explains the energy deficit observed in the damaged heart. The presumption that is key to this statement is that uncoupling proteins indeed uncouple mitochondrial respiration.

Although data on the physiological function of uncoupling proteins in cardiac muscle is scarce, the few data available show similar results as in skeletal muscle, suggesting that the physiological function can be extrapolated from data obtained in skeletal muscle. As such, a rise in uncoupling proteins does not result in uncoupling of mitochondrial respiration from ATP production, as measured by post-depletion phosphocreatine resynthesis rate. ${ }^{2}$

There is compelling evidence that uncoupling proteins are involved in the outward translocation of fatty acid anions away from the mitochondrial matrix. When not all fatty acids can enter the mitochondria via carnitine-palmitoyl-transferase as oxidisable fatty acylCoA esters, the excess enter the mitochondrial matrix via a flip-flop mechanism in their unesterified (non-oxidisable) form where they become deprotonated. The resultant fatty acid anions cannot be oxidised nor leave the matrix due to the proton gradient and are therefore stuck in the matrix where they are harmful to the mitochondria.

Uncoupling proteins can act as outward transporters of these fatty acids, thereby protecting mitochondria in conditions characterised by an oversupply of fatty acids. ${ }^{3}$ In line with this function, uncoupling protein content inversely relates to oxidative capacity. Hence, concentrations of uncoupling protein are 14-fold lower in cardiac muscle than in glycolytic muscle.

Increasing the fat load to the mitochondria by consumption of a high fat diet upregulates uncoupling protein content profoundly in cardiac muscle. ${ }^{4}$ Considering uncoupling protein as a fatty acid anion exporter, the positive association between plasma free fatty acid concentrations and cardiac uncoupling protein content ${ }^{1}$ should be considered a beneficialrather than an unfavourable-adaptive response, attempting to protect the damaged heart from lipotoxicity. In this context, inhibition of fat oxidation, which has been proposed as a treatment for heart disease, would result in upregulation not downregulation of concentrations of uncoupling proteins. ${ }^{5}$ Again, this notion suggests that increased uncoupling protein content is beneficial for the damaged human heart.

Given that uncoupling proteins are unlikely to be responsible for the energy deficit observed in the damaged heart, the ideal treatment should maintain or augment cardiac uncoupling protein concentrations, while reducing the fatty acid load to the heart to prevent lipotoxicity. Finally, it is noteworthy that high fatty acid concentrations might be able to uncouple mitochondrial respiration, irrespective of uncoupling proteins, and thereby contribute to an energy deficit.

We declare that we have no conflict of interest.

Matthijs K C Hesselink, *P Schrauwen p.schrauwen@hb.unimaas.nl

Nutrition and Toxicology Research Institute Maastricht (NUTRIM), Departments of Human Biology (PS) and Movement Sciences (MKCH), Maastricht University, PO Box 616, 6200 MD Maastricht, Netherlands

1 Murray AJ, Anderson RE, Watson GC, Radda GK, Clarke K. Uncoupling proteins in human heart. Lancet 2004; 364: 1786-88. 
2 Hesselink MK, Greenhaff PL, ConstantinTeodosiu D, et al. Increased uncoupling protein 3 content does not affect mitochondrial function in human skeletal muscle in vivo. J Clin Invest 2003; 111: 479-86.

3 Schrauwen P, Saris WH, Hesselink MK. An alternative function for human uncoupling protein 3: protection of mitochondria against accumulation of nonesterified fatty acids inside the mitochondrial matrix. Faseb J 2001; 15: 2497-502.

4 Hoeks J, Hesselink MK, van Bilsen M, et al. Differential response of UCP3 to medium versus long chain triacylglycerols; manifestation of a functional adaptation. FEBS Lett 2003; 555: 631-37.

5 Schrauwen $P$, Hinderling V, Hesselink MK et al. Etomoxir-induced increase in UCP3 supports a role of uncoupling protein 3 as a mitochondrial fatty acid anion exporter. Faseb/ 2002; 16: 1688-90

\section{Uses of Error: diagnosis, detection, and disclosure}

We have been reading the Uses of Error in The Lancet for the unique insight they provide into what being a doctor is like. The accounts are often poignant and draw attention to how errors arise throughout a doctor's career and are long remembered.

149 patients have been described in the 107 essays published between 2001 and 2003, mostly from internal medicine (109 of 149 [73\%])-18 additional Uses of Error are not discussed here because they describe multiple patients or contain general comments on error. The most frequent error type among the 107 essays assessed was associated with diagnosis (78 of 149 [52\%]) usually attributed to misjudgment, a finding consistent with other voluntary reports. ${ }^{1,2}$ In everyday life, however, slips and lapses-where the intention was correct but the execution went astray-are more common. ${ }^{3}$ Why, therefore, is there such an emphasis on diagnostic errors?

Errors in diagnosis are more likely to result in a poor outcome. ${ }^{4,5}$ Doctors might tolerate errors but not poor patient outcomes. Medical training focuses on making the correct diagno- sis, and diagnostic errors undermine the notion of self. Furthermore, others view diagnostic errors negatively and are more likely to consider them negligent than skill-based errors and complications. ${ }^{4.5}$ Finally, the system does not respond kindly to errors of diagnosis. An intention error is less likely to be detected and corrected than a slip or a lapse. ${ }^{3}$ The culture of health care does little to enhance this process.

The reasons doctors give for diagnostic errors provide some insight into the cognitive processes. Diagnostic errors that arose early in the doctor's career were attributed to a lack of knowledge and experience, resulting in poor planning and an error of intention. During the consultant years, however, there were short cuts and often the doctor was working alone in the clinic. In these situations the consultants had the knowledge, but either lapsed or violated their own rules of practice. Strategies to reduce errors and to increase their detection hence need to be tailored to the context.

18 cases describe detection of an error before the patient was harmed. Apart from serendipity, three mechanisms for detection were described: (i) a second person-eg, nurse, technician, other doctor, mother-became involved who made the diagnosis, initiated an action, or made a comment that led to the correction; (ii) the doctor sensed that something was odd; and (iii) a back-up system detected the error (insulin overdose). Since there will never be a system free from errors, research focused on detection and mitigation of mistakes is needed.

Finally, the regular appearance of Uses of Error is contrary to public opinion that doctors wish to operate in a secret society. Many authors expressed a wish to have spoken about their errors earlier, but the mechanisms did not exist. The Uses of Error section is one mechanism but we need more.
We declare that we have no conflict of interest.

*Karen L Dunn, Prasuna Reddy, Glenn Bowes

\section{karen.dunn@rch.org.au}

University of Melbourne Department of Paediatrics, Royal Children's Hospital, Flemington Rd Parkville 3052, Victoria, Australia

1 Runciman WB, Sellen A, Webb RK, et al. Errors, incidents and accidents in anaesthetic practice. Anaesth Intensive Care 1993; 21: 506-19.

2 Wu AW, Folkman S, McPhee SJ, Lo B. Do house officers learn from their mistakes? JAMA 1991; 265: 2089-94.

3 Reason J. Human error. Cambridge: Cambridge University Press, 1990

4 Leape LL, Brennan TA, Laird NM, et al. The nature of adverse events in hospitalized patients: results of the Harvard Medical Practice Study II. N EnglJ Med 1991; 324: 377-84.

5 Wilson RM, Runciman WB, Gibberd RW, Harrison BT, Newby L, Hamilton JD. The Quality in Australian Health Care Study. MedJ Aust 1995; 163: 458-71. 